\title{
Molecular Genetic Profiling of Clinical and Foodborne Strains of Enterococci with High Level Resistance to Gentamicin and Vancomycin
}

Gisela Pourcel ${ }^{1}$, Mónica Sparo ${ }^{1,2^{*}}$, Alejandra Corso ${ }^{3}$, Gastón Delpech ${ }^{1}$, Paula Gagetti $^{3}$, María Marta de Luca ${ }^{2}$, Judith Bernstein ${ }^{2}$, Celia Schell ${ }^{2}$, Sabina Lissarrague $^{2}$ and Juan Ángel Basualdo ${ }^{2}$

${ }^{1}$ Microbiology, School of Medicine, Universidad Nacional del Centro de La Provincia de Buenos Aires, Olavarría, Argentina

${ }^{2}$ Microbiology and Parasitology, School of Medicine, Universidad Nacional de La Plata, La Plata, Argentina

${ }^{3}$ Antimicrobials Unit, National Institute of Infectious Diseases-ANLIS “Dr. Carlos G. Malbrán”, Buenos Aires, Argentina

"Corresponding author: Mónica Sparo, Cátedra de Microbiologíay Parasitología (Sede Tandil), Facultad Ciencias Médicas, UNLP, Gral. Paz 1406, CP 7000, Tandil, Argentina, Tel: +54-0249-442-8797; E-mail: monicasparo@gmail.com

Received date: December 23, 2016; Accepted date: January 13, 2017; Published date: January 23, 2017

Copyright: (C) 2017 Pourcel G, et al. This is an open-access article distributed under the terms of the Creative Commons Attribution License, which permits unrestricted use, distribution, and reproduction in any medium, provided the original author and source are credited.

\begin{abstract}
Enterococci often acquire antimicrobial resistance through horizontal gene transfer. Relatedness between enterococci with high level resistance to gentamicin and vancomycin isolated from humans, food and hospital environment in Tandil County (Argentina) was investigated. PCR amplification for species determination was carried out. Resistance to seven antimicrobials was studied; virulence genes (esp, cylA), vancomycin and gentamicin resistance genes were investigated. In the isolates with high level antimicrobial resistance (gentamicin, vancomycin), pulse-field gel electrophoresis was performed. Vancomycin-resistant $E$. faecium $(n: 13)$ were recovered from human, food and hospital environment samples. All the isolates expressed high-level vancomycin and teicoplanin (vanA genotype), as well high-level gentamicin and streptomycin resistance. Vancomycin-resistant $E$. faecium were distributed among seven clonal types; esp gene was detected in clinical strains. There was no clonal relationship with food vanA E. faecium, but these strains could pose a risk in intra/inter genus transfer of vanA determinant to human-adapted strains. High-level gentamicin resistant $E$. faecalis $(n: 7)$ were recovered from human and food samples. Glycopeptide resistance was not observed; cylA gene was detected in most of the clinical high-level gentamicin resistant $E$. faecalis isolates. PFGE patterns showed four clonal types in high-level gentamicin resistant $E$. faecalis strains; there was demonstrated clonal relatedness between isolates from different origin. In Argentina, this is the first study showing a clonal relationship between high-level gentamicin resistant $E$. faecalis isolated from food and humans. These results encourage the study of dissemination of clonal complexes with mobile resistance genes.
\end{abstract}

Keywords: Enterococci; Relatedness; Food; Humans; Environment

\section{Introduction}

Enterococci are intrinsically resistant to many antimicrobials groups. Furthermore, these bacteria are capable of acquiring drug resistance genes through horizontal gene transfer, such as high level aminoglycosides and vancomycin resistance genes [1,2].

Enterococci colonize raw and fermented meat, as well as dairy products, since they are part of the indigenous microbiota of mammal's gastrointestinal tract and are able to survive under adverse environmental conditions $[3,4]$.

Enterococcus faecalis and Enterococcus faecium have been recognized as etiological agents of bacteremia, meningitis, endocarditis, urinary tract and neonatal infections. Both species are relevant pathogens for immunosuppressed patients or with prolonged hospitalization [5-8].

Enterococci remain for long time-periods on environmental surfaces, including medical equipment, bed rails and doorknobs. Also, they are tolerant to heat, chlorine and some alcohol-based preparations [9].

In enterococcal species, vancomycin resistance can be associated with different van genotypes and Van phenotypes. VanA resistance is mediated by transposon $\operatorname{Tn} 1546$ or closely related elements. Expression of vanA gene leads to inducible high-level vancomycin (Minimum Inhibitory Concentration, MIC, $\geq 64 \mu \mathrm{g} / \mathrm{mL}$ ) and teicoplanin ( $\mathrm{MIC} \geq 16 \mu \mathrm{g} / \mathrm{mL}$ ) resistance, while $\operatorname{van} B$ gene encodes for variable levels of inducible vancomycin resistance. $\operatorname{Van} A$ is the most frequent glycopeptide resistance type in clinical enterococci. Nowadays, there is an increasing concern about van $A$ plasmidmediated transfer to methicillin-resistant Staphylococcus aureus [10-12].

Over the last decades, detection of $\operatorname{van} A$ genotype in $E$. faecium from animals and from food of animal origin has been reported. Initially, vancomycin resistance was linked with the use of avoparcin (glycopeptide) as an animal growth promoter in the European Union, EU [13-15]. After avoparcin was banned, glycopeptide-resistance persisted, likely due to co-selection processes. However, at the same time of avoparcin ban in the $\mathrm{EU}$, vancomycin-resistant $E$. faecium were not isolated from animal food products in the US [16,17]. In Argentina, Delpech et al. [18] recovered vancomycin-resistant $E$. faecium from artisanal salami, cow cheese and goat cheese.

The incidence of health-care associated infectious diseases produced by vancomycin-resistant $E$. faecium in US hospitals has increased significantly, becoming a nosocomial pathogen almost as prevalent as E. faecalis [19]. 
Frequently, hospitalized patients are treated with broad spectrum antimicrobials. Therefore, presence of $\operatorname{Van} A$ or $\operatorname{Van} B$ vancomycinresistant enterococci in patients' gastrointestinal tract and the risk of invasive infections can be significantly increased. In humans, $E$. faecium is the main reservoir of $\operatorname{Van} A$ and $\operatorname{Van} B$ type resistance. In recent years, worldwide, colonization with vancomycin-resistant $E$. faecium was considered endemic in many hospitals. Antimicrobial use in patients seems to be a critical factor related to vancomycin-resistant enterococci infections [20-22].

In South America, a multicenter study found that, ca. $22 \%$ of enterococcal infections were caused by multi-resistant $E$. faecium, similarly to what was reported in the US [23]. In Argentina, Corso et al. [24], through a nation-wide antimicrobial resistance survey, proved that most of vancomycin resistant enterococci carried van $A$ gene (98\%). In addition, these strains, expressed high-level resistance to gentamicin (77.2\%) and streptomycin (95.8\%).

Many putative virulence factors from $E$. faecium have been identified. One of the most relevant is a large surface protein (Esp) covalently linked to the bacterial cell wall. Leavis et al. [25] demonstrated that, in E. faecium, esp gene was encoded in a large pathogenicity island and its presence was associated with nosocomial outbreaks.

In enterococci, acquisition of high-level gentamicin resistance (MIC $\geq 2,000 \mu \mathrm{g} / \mathrm{mL}$ ) is a significant therapeutic problem, particularly for patients with severe infections. High-level aminoglycoside resistance makes ineffective the synergistic effect between aminoglycosides and a cell-wall-active agent, e.g. beta-lactams or vancomycin. aac $(6)$-Ie-aph (2")-Ia gene, associated with high-level gentamicin resistance, is widely spread in E. faecalis. This gene has been detected in strains from human infections and among enterococci from food of animal origin $[26,27]$. Bifunctional enzyme AAC6'-Ie-APH2' '-Ia confers resistance to available aminoglycosides, except for streptomycin. aac (6')-Ieaph(2")-Ia gene is generally flanked by inverted repeats of IS256, making up composite transposons, such as Tn5281 in E. faecalis. Fast dissemination of the genetic determinant led to consider the impact of its horizontal transferability among enterococcal species from different origin. Hence, human enterococcal isolates are not the only ones to be regarded as a reservoir of gentamicin resistance genes [28]. Among high-level gentamicin resistant enterococci, chromosomal $a p h\left(2^{\prime \prime}\right)-I b$, $\operatorname{aph}\left(2^{\prime \prime}\right)$-Id and plasmidic aph(2')-Ic encode for gentamicin modifying enzymes as well [29].

Recently, our group studied antimicrobial resistance profiles in enterococci from minced meat, cow and goat cheese. In E. faecalis recovered from these products, high-level gentamicin resistance was detected [18].

Cytolysin is a chromosomal or plasmid encoded toxin with lytic activity against eukaryotic cells, helping enterococci to escape from host's immune response [30]. In human infections and experimental models, such as enterococcal endocarditis, cytolysin production has shown to contribute with virulence [31]. Huycke et al. [32] reported that ca. $60 \%$ of $E$. faecalis isolated from infection sites produced cytolysin and it was associated with a five fold-increased risk of acutely terminal outcome in patients with bacteremia. Moreover, high-level gentamicin resistant (HLGR)-cytolysin producer $E$. faecalis influence clinical and microbiological resolution of severe infectious diseases [33].
In Argentina, genomic relationship between vancomycin-resistant $E$. faecium and $E$. faecalis isolates with high-level gentamicin resistance from human and food origin has not been studied so far.

The aim of this study was to investigate the relatedness between HLGR $E$. faecalis and vancomycin-resistant $E$. faecium strains isolated from humans, food and hospital environment in Tandil City, Argentina.

\section{Methods}

\section{Samples}

Enterococci were recovered from the following sources: human, hospital environment and food of animal origin. Isolates were collected during the period January-December 2013, in Tandil County, at the Southeast region of Buenos Aires Province, Argentina. All isolates were stored, by triplicate, in brain heart infusion (BHI) broth with $30 \%$ glycerol at $-70^{\circ} \mathrm{C}$.

Human source: Samples for microbiological diagnosis of invasive infections caused by enterococci were collected from ICU's (Intensive Care Unit) patients at Hospital Ramon Santamarina de Tandil (HRS).

Samples: Blood, cerebrospinal, abdominal, pleural and synovial puncture fluids. They were inoculated into BacT/ALERT culture bottles (BacT/ALERT ${ }^{\circ}$ 3D Microbial Detection System, BioMérieux, Argentina). One significant isolate per patient, with an identifying number, was included in the study.

Hospital environment: Samples from surveillance cultures, in order to investigate the presence of vancomycin-resistant E. faecium in ICUHRS. Study of ICU's environmental contamination was performed investigating the surfaces close to patients (mattresses, bed rails and doorknobs) and medical instruments in contact with them. This procedure was carried out each time a vancomycin-resistant $E$. faecium was isolated from a patient. Samples were spread on bile esculin agar azide (BEEA) with $8 \mu \mathrm{g} / \mathrm{mL}$ of vancomycin and incubated for $48 \mathrm{~h}$ at $35^{\circ} \mathrm{C}$. Each vancomycin-resistant $E$. faecium isolate from different places was labelled with a numerical identification code.

In all patients, admitted and discharged from the UCI, rectal swabs were done and processed as environmental samples.

Food: Artisanal meat and dairy products were purchased from 20 food retailers of Tandil County (ET1-ET20). In total, 146 samples (35 goat cheese, 32 cow cheese, 37 salami, 42 minced meat) were analyzed. Samples were sent (refrigerated at $4^{\circ} \mathrm{C}$ ) to the Microbiology Laboratory and immediately processed.

Sampling and isolation techniques used have been previously described by Delpech et al. [26]. Additionally, enrichment in BHI broth with vancomycin $(8 \mu \mathrm{g} / \mathrm{mL})$ was performed for all samples. After incubation for $24 \mathrm{~h}$ at $35^{\circ} \mathrm{C}, 10 \mu \mathrm{L}$ of each enrichment culture were spread on BEEA with vancomycin $(8 \mu \mathrm{g} / \mathrm{mL})$.

\section{Susceptibility tests}

MICs of all enterococcal isolates were determined by the agar dilution method, according to Clinical and Laboratory Standards Institute's (CLSI) recommendations [34]. The following antimicrobials, used in human medicine, were tested: ampicillin, ciprofloxacin, linezolid, vancomycin, teicoplanin, gentamicin and streptomycin. Quality control strains: E. faecalis ATCC 29212 (susceptible to vancomycin and gentamicin), E. faecalis ATCC 51299 (resistant to 
Citation: Pourcel G, Sparo M, Corso A, Delpech G, Gagetti P, et al. (2017) Molecular Genetic Profiling of Clinical and Foodborne Strains of Enterococci with High Level Resistance to Gentamicin and Vancomycin. Clin Microbiol 6: 272. doi:10.4172/2327-5073.1000272

Page 3 of 8

gentamicin and vancomycin) and E. faecium ATCC 51559 (multidrugresistant).

Phenotypic characterization was performed by Gram staining, catalase production, hydrolysis of pyrrolidonyl beta-naphthylamide, and growth in BHI broth with $6.5 \% \mathrm{NaCl}$. Species-level characterization was carried out by hydrolysis tests (arginine, pyruvate and methyl- $\alpha$-d-glucopyranoside), tolerance to tellurite $0.04 \%$, fermentation of carbohydrates (mannitol, arabinose, sorbitol, sucrose, raffinose, and sorbose), motility in thioglycolate broth, and agar pigment production [27].

Phenotypic confirmation was done using the Automated VITEK 2 System (BioMérieux, Argentina).

Genomic DNA was extracted from phenotypically identified $E$. faecalis and $E$. faecium isolates by a previously described boiling method [35]. Molecular identification (polymerase chain reaction, PCR) was performed.

For genus confirmation, the protocol described by Ke et al. [36] was used. A tuf gene fragment ( $803 \mathrm{bp}$ ), encoding for a specific elongation factor of the genus Enterococcus was amplified (Table 1). One nanogram of genomic DNA was transferred directly to a $19 \mu \mathrm{L}$ PCR mixture containing $50 \mathrm{mM} \mathrm{KCl}, 10 \mathrm{mM}$ Tris- $\mathrm{HCl}(\mathrm{pH}: 9.0), 0.1 \%$ Triton X-100, $2.5 \mathrm{mM} \mathrm{MgCl} 2,0.2 \mathrm{mM}$ each Enterococcus-specific primer, $200 \mathrm{mM}$ each deoxynucleoside triphosphate, $3.3 \mathrm{mg} / \mathrm{mL}$ of bovine serum albumin and $0.5 \mathrm{U}$ of Taq polymerase. The PCR mixtures were subjected to thermal cycling: $3 \mathrm{~min}$ at $96^{\circ} \mathrm{C}$; then, 40 cycles of $1 \mathrm{~s}$ at $95^{\circ} \mathrm{C}$ (denaturation) and $30 \mathrm{~s}$ at $55^{\circ} \mathrm{C}$ (annealingextension step).

\begin{tabular}{|c|c|c|}
\hline Gene (type) & Nucleotide sequence $\left(5^{\prime}-3^{\prime}\right)$ & Annealing Temperature $\left({ }^{\circ} \mathrm{C}\right)$ \\
\hline \multirow{2}{*}{ tuf (Genus marker) } & TACTGACAAACCATTCATGATG & \multirow{2}{*}{$55^{\circ} \mathrm{C}$} \\
\hline & AACTTCGTCACCAACGCGAAC & \\
\hline \multirow{2}{*}{$d d l_{\text {E.faecalis }}$ (Species identfication) } & ATCAAGTACAGTTAGTCT & \multirow{2}{*}{$54^{\circ} \mathrm{C}$} \\
\hline & ACGATTCAAAGCTAACTG & \\
\hline \multirow{2}{*}{$d d l_{\text {E.faecium }}$ (Species identification) } & TAGAGACATTGAATATGCC & \multirow{2}{*}{$54^{\circ} \mathrm{C}$} \\
\hline & TCGAATGTGCTACAATC & \\
\hline \multirow{2}{*}{ cylA (Virulence factor) } & ATGGATGGGACAGATGGAAA & \multirow{2}{*}{$54^{\circ} \mathrm{C}$} \\
\hline & AGCTGCGCTTAGTTCTGGAG & \\
\hline \multirow{2}{*}{ esp (Virulence factor) } & GGAACGCCTTGGTATG & \multirow{2}{*}{$58^{\circ} \mathrm{C}$} \\
\hline & CCGCTTTTGGTGATTC & \\
\hline \multirow{2}{*}{ vanA (Glycopeptide resistance) } & GTAGGCTGCGATATTCAAAGC & \multirow{2}{*}{$54^{\circ} \mathrm{C}$} \\
\hline & CGATTCAATTGCGTAGTCCAA & \\
\hline \multirow{2}{*}{ vanB (Glycopeptide resistance) } & GGTATCAAGGAAACCTC & \multirow{2}{*}{$54^{\circ} \mathrm{C}$} \\
\hline & CTTCCGCCATCATAGCT & \\
\hline \multirow{2}{*}{$\begin{array}{l}\text { aac(6)- le- aph(2")-la (Aminoglycoside } \\
\text { resistance) }\end{array}$} & CAGGAATTTATCGAAAATGGTAGAAAAG & \multirow{2}{*}{$54^{\circ} \mathrm{C}$} \\
\hline & CACAATCGACTAAAGAGTACCAATC & \\
\hline \multirow{2}{*}{ aph (2")-Ib (Aminoglycoside resistance) } & TATGGATTCATGGTTAACTTGGACGCTGAG & \multirow{2}{*}{$54^{\circ} \mathrm{C}$} \\
\hline & ATTAAGCTTCCTGCTAAAATATAAACATCTCTGCT & \\
\hline \multirow{2}{*}{ aph (2')-Ic (Aminoglycoside resistance) } & GAAGTGATGGA AATCCCTTCGTG & \multirow{2}{*}{$54^{\circ} \mathrm{C}$} \\
\hline & GCTCTAACCCTTCAGAAATCCAGTC & \\
\hline \multirow{2}{*}{ aph (2")-Id (Aminoglycoside resistance) } & GGTG GTTTTTACAGGAATGCCATC & \multirow{2}{*}{$54^{\circ} \mathrm{C}$} \\
\hline & СССТСТTСАТАССАAТССАТАТАACC & \\
\hline
\end{tabular}

Table 1: Primers for identification of enterococci and antimicrobial resistance genes by PCR.

For species identification, PCR with species-specific primers: $d d l_{\text {E.faecalis }}\left(941 \mathrm{bp}\right.$ ) and $d d l_{\text {E.faecium }}(550 \mathrm{bp}$ ), for the chromosomally encoded D-alanine: D-alanine (D-Ala:D-Ala) ligases was carried out. A final volume of $100 \mu \mathrm{L}$ containing $250 \mathrm{ng}$ of DNA as template; 50 pmol of each oligodeoxynucleotide primer; $500 \mathrm{mM}$ (each) dATP, dCTP, dGTP and dTTP; $67 \mathrm{mM}$ Tris- $\mathrm{HCl}$ ( $\mathrm{pH} \mathrm{8.8);} 7 \mathrm{mM} \mathrm{MgCl}_{2} ; 17$ $\mathrm{mM}$ ammonium sulfate; $10 \mathrm{mM}$ b-mercaptoethanol; and $2 \mathrm{U}$ of Taq DNA polymerase. The cycles used were $94^{\circ} \mathrm{C}$ for $2 \mathrm{~min}$ for the first 
Citation: Pourcel G, Sparo M, Corso A, Delpech G, Gagetti P, et al. (2017) Molecular Genetic Profiling of Clinical and Foodborne Strains of Enterococci with High Level Resistance to Gentamicin and Vancomycin. Clin Microbiol 6: 272. doi:10.4172/2327-5073.1000272

Page 4 of 8

cycle; $94^{\circ} \mathrm{C}$ for $1 \mathrm{~min}, 54^{\circ} \mathrm{C}$ for $1 \mathrm{~min}$, and $72^{\circ} \mathrm{C}$ for $1 \mathrm{~min}$ for the next 30 cycles; and $72^{\circ} \mathrm{C}$ for $10 \mathrm{~min}$ for the last cycle [37].

For detection of the cytolysin encoding gene cylA, PCR was performed in a $25 \mu \mathrm{L}$ total volume containing 20 pmol of each primer (517 bp fragment), $200 \mathrm{mM}$ of each dNTP, $1 \mathrm{U}$ of Taq polymerase, 1.5 $\mathrm{mm} \mathrm{MgCl}, 2.5 \mathrm{~mL}$ of $10 \mathrm{X}$ PCR buffer and $2 \mu \mathrm{L}$ of template DNA. Reaction settings: $2 \mathrm{~min}$ at $94^{\circ} \mathrm{C}$ (initial denaturation) followed by 30 cycles of $30 \mathrm{~s}$ at $90^{\circ} \mathrm{C}$ (denaturation), $30 \mathrm{~s}$ at $54^{\circ} \mathrm{C}$ (annealing) and 1 min at $72^{\circ} \mathrm{C}$ (extension). A final extension cycle was performed at $72^{\circ} \mathrm{C}$ for $8 \min [27]$.

Enterococcal strains were screened for the esp gene by PCR, according to the protocol of Coque et al. [38]. Primers were used for amplifying an $800 \mathrm{bp}$ gene fragment, encoding for esp: $5^{\prime}$ GGAACGCCTTGGTATG-3' and 5'-CCGCTTTTGGTGATTC- 3 '. The reaction mixture consisted of $25 \mu \mathrm{L}$ PCR master mix, $5 \mu \mathrm{L}$ primers $(2 \mu \mathrm{M}), 15 \mu \mathrm{L}$ sterile water and $5 \mu \mathrm{L}$ of bacterial DNA. PCR was carried out with the following thermal cycling profile: initial activation step at $95{ }^{\circ} \mathrm{C}$ for $15 \mathrm{~min} ; 30$ cycles of denaturation at $90^{\circ} \mathrm{C}$ for 30 seconds, annealing at $58^{\circ} \mathrm{C}$ for $1 \mathrm{~min}$, and extension at $72^{\circ} \mathrm{C}$ for $1 \mathrm{~min}$; final extension at $72^{\circ} \mathrm{C}$ for $10 \mathrm{~min}$.

Resistance genes were detected by PCR using specific primers for the aminoglycoside-modifying enzymes $\operatorname{aac}\left(6^{\prime}\right)$-Ie-aph( $\left(2^{\prime \prime}\right)$-Ia (369 bp), aph (2')-Ib (867 bp), aph (2')-Ic (444 bp) and aph (2'')-Id (641 bp) genes. Detection of high-level gentamicin resistance genes was done according to Sparo et al. [27]. PCR was performed in a final volume of $25 \mu \mathrm{L}$, with 20 pmol of each primer, 1-2 colonies of each bacterial isolate, $200 \mu \mathrm{M}$ of each dNTP, $1 \mathrm{U}$ of Taq polymerase, $1.5 \mu \mathrm{M} \mathrm{MgCl}_{2}$, $2.5 \mu \mathrm{L}$ PCR 10X buffer and $2 \mu \mathrm{L}$ of template DNA. Setting: a first cycle, $2 \mathrm{~min}$ at $94^{\circ} \mathrm{C}$; followed by 30 cycles of $30 \mathrm{~s}$ at $90^{\circ} \mathrm{C}, 30 \mathrm{~s}$ at $54^{\circ} \mathrm{C}$ and 1 min at $72^{\circ} \mathrm{C}$. A final extension cycle for $8 \mathrm{~min}$ at $72^{\circ} \mathrm{C}$ was done.

PCR for detection of $\operatorname{van} A$ and $\operatorname{van} B$ genes fragments (732 bp and $625 \mathrm{bp}$, respectively), which encode for D-Ala:D-Ala ligases of altered substrate specifity, was carried out according to the same protocol of Dutka-Malen et al. [37] for detection of $d d l$ genes.

\section{PFGE typing}

Bacterial isolates were grown overnight in BHI broth. Chromosomal DNA was prepared in agarose plugs, digested with the restriction enzyme SmaI. DNA fragments were separated in a CHEF-DRIII apparatus (Bio-Rad Laboratories, Richmond, CA, USA), following the protocol of Corso et al. [24]. SmaI was chosen upon the base composition (\% $\mathrm{G}+\mathrm{C}$ content) of the DNA of the microorganisms in study. In the case of low GC bacteria, as $E$. faecalis and E. faecium, SmaI (CCCGGG) is preferred, since it is advisable to use enzymes which recognize relatively few sites on the genome and give a resolvable and informative number of DNA fragments on the PFGE gel. Lambda ladder (New England Biolabs, Beverly, MA, USA) was used as molecular size standard. Similarity between isolates was determined by visual comparison of isolates DNA banding pattern. Interpretation of band patterns was carried out according to Tenover et al. [39].

Isolates were defined as distinct strain types, or unrelated, if their PFGE patterns differed by more than six bands. Types were named using a capital letter following the alphabet order (e.g. type A, B, C, D). Subtypes were defined as strains that differed by $2-6$ bands, which were considered closely or possibly related, and were named using an Arabic number (e.g. subtype D1, D2) following the capital letter. Those isolates whose restriction patterns had the same number and size of bands were considered genetically indistinguishable and were assigned to the same strain type.

\section{Results}

Vancomycin-resistant E. faecium were isolated from samples from different sources: human, hospital environment and food of animal origin. Food enterococci were recovered from samples collected at five retailers (ET1, ET2, ET3, ET4, ET5).

Clinical vancomycin-resistant $E$. faecium were isolated from six $(n=6)$ patients with invasive infections, five from hemoculture and one from abdominal puncture fluid (Figure 1). Also, vancomycin-resistant $E$. faecium, were recovered from $n=3$ rectal swabs from patients without enterococcal invasive diseases and $n=1$ in a mattress of a patient (HRSER460) near other one with a positive rectal culture.

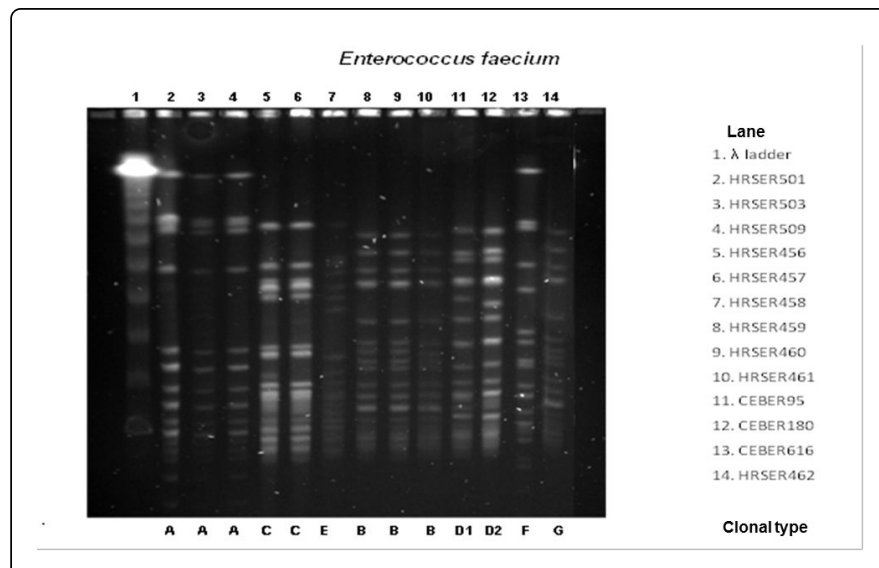

Figure 1: SmaI-PFGE patterns in vancomycin-resistant Enterococcus faecium isolates (Lane 1: lambda ladder; Lane 2: $E$. faecium EHRSER501 (human); Lane 3: E. faecium HRSER503 (human); Lane 4: HRSER509 (human); Lane 5: HRSER456 (human); Lane 6: HRSER457 (human); Lane 7: HRSER458 (human); Lane 8: HRSER459 (environment); Lane 9: HRSER460 (human); Lane 10: HRSER461 (human); Lane 11: CEBER95 (food); Lane 12: CEBER180 (food); Lane 13: CEBER616 (food); Lane 14: HRSER462 (human)).

Three vancomycin-resistant $E$. faecium were isolated from food: handmade "salame", cow cheese and sheep cheese from ET1, ET3 and ET5, respectively. In all vancomycin-resistant $E$. faecium ( $n=13)$, vanA gene was detected and MICs were as follow: vancomycin $\geq 256 \mu \mathrm{g} / \mathrm{mL}$; teicoplanin $\geq 256 \mu \mathrm{g} / \mathrm{mL}$; linezolid $\leq 2.0 \mu \mathrm{g} / \mathrm{mL}$; streptomycin $>2,000$ $\mu \mathrm{g} / \mathrm{mL}$. Moreover, human and hospital environment vancomycinresistant $E$. faecium were resistant to ampicillin (MIC $\geq 32 \mu \mathrm{g} / \mathrm{mL}$ ), ciprofloxacin $\geq 8.0 \mu \mathrm{g} / \mathrm{mL}$ and showed high-level resistance to gentamicin (MIC $>500 \mu \mathrm{g} / \mathrm{mL}$ ). In contrast, vancomycin-resistant $E$. faecium isolates from food were susceptible to ampicillin $(\mathrm{MIC} \leq 2.0$ $\mu \mathrm{g} / \mathrm{mL}$ ), ciprofloxacin (MIC 1.0-2.0 $\mu \mathrm{g} / \mathrm{mL}$ ) and without high-level gentamicin resistance $(\mathrm{MIC}<500 \mu \mathrm{g} / \mathrm{mL})$.

Vancomycin-resistant $E$. faecium isolates could be differentiated in seven clonal types: VRE- A, VRE- B, VRE-C, VRE-D, VRE-E, VRE- F and VRE-G. Clone A, were detected from two blood culture isolates, from patients HRSER501 and HRSER503 with invasive infections and other patient (HRSER509) with rectal colonization; all of them hospitalized in ICU for the same period. Clone B included three 
Citation: Pourcel G, Sparo M, Corso A, Delpech G, Gagetti P, et al. (2017) Molecular Genetic Profiling of Clinical and Foodborne Strains of Enterococci with High Level Resistance to Gentamicin and Vancomycin. Clin Microbiol 6: 272. doi:10.4172/2327-5073.1000272

Page 5 of 8

isolates, a positive hemoculture from patient HRSER461 and an environment contamination of a mattress following the discharge from ICU of patient HRSER459 and a rectal colonization of a patient (HRSER460) next to him; both without enterococcal invasive disease Clone $\mathrm{C}$ was represented by 2 clinical isolates from hemoculture and an abdominal puncture fluid (patients HRSER456 and HRSER457), admitted in ICU at different time. Clone D was identified in two isolates of food, "salame" and sheep cheese, from different industrial plants (ET1 and ET4), not produced in the same period. Those isolates were identified as belonging to two subtypes (D1, D2) and considered as closely related. Clonal types E (hemoculture), F (cow cheese) and G (rectal swab) were represented by a single isolate each.

Only hospital vancomycin-resistant $E$. faecium isolates carried $e s p$ gene, excluding clonal type VRE-G.

During 2013, from 10 patients were recovered E. faecalis producing invasive infections and 4/10 of them showed high-level gentamicin resistance. Regarding food of animal origin, E. faecalis was isolated from different samples: minced meat for hamburgers, 5; regional handmade "salame", 2; sheep cheese, 4 ; cow cheese, 3 . HLGR $E$. faecalis $(3 / 14)$ were recovered from minced meat for hamburgers elaborated in ET4 (2/3) and "salame" (1/3), manufactured in ET1. Those isolates were recovered in different seasons: summer (January) and fall (April).

All E. faecalis isolates expressing high-level gentamicin resistance carried the $\operatorname{aac}\left(6^{\prime}\right)$ - Ie- aph $\left(2^{\prime \prime}\right)$-Ia gene. None showed multiple antimicrobial resistance. Determined MICs were: gentamicin $>500$ $\mu \mathrm{g} / \mathrm{mL}$; streptomycin $\leq 500 \mu \mathrm{g} / \mathrm{mL}$; ampicillin $\leq 2.0 \mu \mathrm{g} / \mathrm{mL}$; linezolid $\leq$ $2.0 \mu \mathrm{g} / \mathrm{mL}$; ciprofloxacin $\leq 0.5-\geq 8.0 \mu \mathrm{g} / \mathrm{mL}$; vancomycin $\leq 1.0 \mu \mathrm{g} / \mathrm{mL}$ and teicoplanin $\leq 0.5 \mu \mathrm{g} / \mathrm{mL}$.

Most of the clinical HLGR E. faecalis carried cylA gene; were recovered from blood $(n=2)$ and abdominal puncture fluid $(n=1)$. In food enterococci, cylA was detected in minced meat isolates $(n=2)$ from ET4.

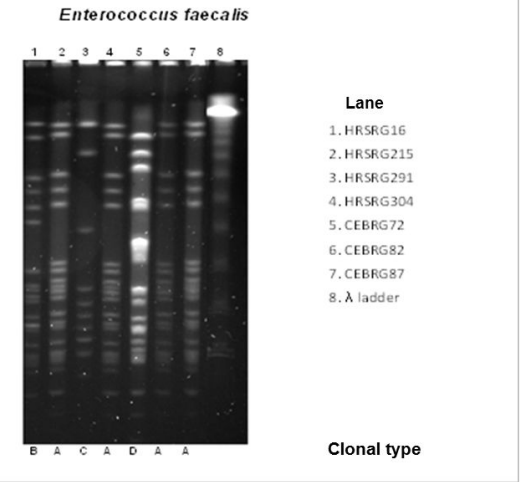

Figure 2: SmaI-PFGE patterns in high level gentamicin resistant Enterococcus faecalis isolates (Lane 1: E. faecalis HRSRG16 (human); Lane 2: E. faecalis HRSRG215 (human); Lane 3: E. faecalis HRSRG291 (human); Lane 4: E. faecalis HRSRG304 (human); Lane 5: E. faecalis CEBRG72 (food); Lane 6: E. faecalis CEBRG82 (food); Lane 7: E. faecalis CEBRG87 (food); Lane 8: lambda ladder).

SmaI-PFGE (Figure 2) showed that seven HLGR E. faecalis isolates were differentiated in four clonal types: EFA-A, EFA-B, EFA-C and EFA-D. Clone A was represented by four isolates, two from UCI's patients HRSRG215 and HRSRG304 in the same period, isolated from blood and abdominal puncture fluid, respectively, and two from food, in minced meat from the same industrial plant (ET4) and period. Clones B (hemoculture), C (hemoculture) and D (handmade "salame") included one isolate each. Moreover, cylA gene was detected in pulsotypes EFA-A and EFA-B (Table 2).

\section{Discussion}

In the present study, $\operatorname{van} A E$. faecium was recovered from handmade "salame" and cheese. Previously, Barbosa et al. [40] did not detect vancomycin resistance in $E$. faecium isolated from traditional fermented meat products. Recently, Ribeiro et al. [41] found van $A E$. faecium isolated from a traditional Portuguese dry fermented sausage. Therefore, the presence of $\operatorname{van} A E$. faecium is variable according to each analyzed geographic region.

Worldwide, VanA phenotype is linked to most of the human cases of vancomycin resistant enterococci, and is mainly carried by $E$. faecium. Spread of vancomycin-resistant $E$. faecium is a major global issue due to its persistence in hospital environment, limited therapeutic alternatives, and plasmidic van $A$ transfer [42].

Vancomycin-resistant E. faecium are the second most common cause of nosocomial infections in the US [43]. In Europe, vancomycinresistant $E$. faecium prevalence is variable, ranging from less than $1 \%$ in France and Sweden to higher than 20\% in Greece, Ireland, Portugal and the United Kingdom [44].

In Argentina, vancomycin-resistant E. faecium infections have been reported since 1998. In different hospitals predominance of one epidemic clone carrying $\operatorname{van} A$ has been observed, with an increased incidence of vancomycin-resistant $E$. faecium clonal spread [24]. In 2014, according to the Antimicrobial Resistance Surveillance Network WHONET-Argentina (89 Microbiology Laboratories), clinical $E$. faecium shows a high rate $(61 \%)$ of vancomycin resistance (www.antimicrobianos.com.ar).

In the current study, one pulso-type (VRE-B) was observed in two patients and in the mattress of another one, suggesting strain dissemination between patients and the environment. Kalocheretis et al. [45] detected vancomycin-resistant $E$. faecium transmission through a contaminated environment in different hospitals areas.

It should be noted that as a result of appearance of invasive infections at ICU-HMRS, surveillance of vancomycin-resistant $E$. faecium carriage in patients was started.

It is important to highlight that food vancomycin-resistant $E$. faecium isolates were susceptible to ampicillin and ciprofloxacin, but those of hospital origin were resistant to both antimicrobials. Ampicillin and, frequently, fluoroquinolone resistance are phenotypic markers for differentiating hospital and community vancomycinresistant E. faecium [46].

In this research, only hospital E. faecium strains carried esp gene, also reported by Willems \& Bontem [20]. According to Willems et al. [47], emergence of E. faecium ST-17 lineage in hospital settings started with adaptive changes, acquiring ampicillin resistance and a novel putative pathogenicity island, linked to esp gene. In CC17 strains, esp gene brings advantages in the adaptation to the hospital environment. Furthermore, the strong linkage between ampicillin and ciprofloxacin resistant E. faecium and CC17 has been widely accepted [48]. 
Citation: Pourcel G, Sparo M, Corso A, Delpech G, Gagetti P, et al. (2017) Molecular Genetic Profiling of Clinical and Foodborne Strains of Enterococci with High Level Resistance to Gentamicin and Vancomycin. Clin Microbiol 6: 272. doi:10.4172/2327-5073.1000272

Page 6 of 8

\begin{tabular}{|c|c|c|c|c|c|}
\hline Isolate & Source & Sample & cylAlesp ${ }^{\dagger}$ & HLGR/VR* & Smal-PFGE \\
\hline \multicolumn{6}{|l|}{ E. faecium } \\
\hline VREf-HRSER456 & Clinical, ICU\#† & Abdominal puncture fluid ${ }^{* *}$ & $-/+$ & $-/+$ & VREf-C \\
\hline VREf-HRSER457 & Clinical, ICU, ID & Hemoculture & $-/+$ & $-/+$ & VREf-C \\
\hline VREf-HRSER458 & Clinical, ICU, ID & Hemoculture & $-/+$ & $-/+$ & VREf-E \\
\hline VREf-HRSER459 & ICU. Environment & Mattress & $-/+$ & $-/+$ & VREf-B \\
\hline VREf-HRSER460 & Clinical, ICU, RC§ & Rectal swab & $-/+$ & $-/+$ & VREf-B \\
\hline VREf-HRSER461 & Clinical, ICU, ID & Hemoculture & $-1+$ & $-/+$ & VREf-B \\
\hline VREf-HRSER462 & Clinical, ICU, ID & Rectal swab & $-/-$ & $-/+$ & VREf-G \\
\hline VREf-HRSER501 & Clinical, ICU, ID & Hemoculture & $-/+$ & $-/+$ & VREf-A \\
\hline VREfHRSER503 & Clinical, ICU. ID & Hemoculture & $-/+$ & $-/+$ & VREf-A \\
\hline VREf-HRSER509 & Clinical, RC & Rectal swab & $-/+$ & $-/+$ & VREf-A \\
\hline VREf-CEBER95 & Food, ET1§§ & "salame" & $-/+$ & $-/+$ & VREf-D1 \\
\hline VREf-CEBER180 & Food, ET3 & Sheep cheese & $-/+$ & $-1+$ & VREf-D2 \\
\hline VREfCEBER616 & Food, ET5 & Cow cheese & $-/+$ & $-/+$ & VREf-F \\
\hline \multicolumn{6}{|l|}{ E. faecalis } \\
\hline EFA-HRSRG16 & Clinical, ICU, ID & Hemoculture & $+/-$ & $+/-$ & EFA-B \\
\hline EFA-HRSRG215 & Clinical, ICU, ID & Hemoculture & $+/-$ & $+/-$ & EFA-A \\
\hline EFA-HRSRG291 & Clinical, ICU, ID & Hemoculture & $-/-$ & $+/-$ & EFA-C \\
\hline EFA-HRSRG304 & Clinical, ICU, ID & Abdominal puncture fluid & $+/-$ & $+/-$ & EFA-A \\
\hline EFA-CEBRG72 & Food, ET1 & "salame" & $-/-$ & $+/-$ & EFA-D \\
\hline EFA-CEBRG82 & Food, ET4 & Minced meat & $+/-$ & $+/-$ & EFA-A \\
\hline EFA-CEBRG87 & Food, ET4 & Minced meat & $+/-$ & $+/-$ & EFA-A \\
\hline
\end{tabular}

Table 2: Source and SmaI-PFGE of enterococcal isolates.

In this study, clonal complexes of vanA E. faecium were not investigated. Nevertheless, the presence of esp gene, ampicillin and ciprofloxacin resistance could suggest that clinical enterococcal isolates might belong to clonal complex 17, since its spread in Argentina has been reported (http://antimicrobianos.com.ar/2010/?cat=9).

The $\operatorname{van} A$ gene is contained in Tn1546 or its derivatives, usually located on transferable plasmids. Plasmids are readily found in enterococci, and are common that clinical and commensal strains harbor a number of such elements. They comprise an important fraction of the auxiliary genome, and are responsible for much of the horizontal gene transfer that has allowed antibiotic and virulence traits to converge in hospital adapted lineages. Remarkably, different plasmid types occur in E. faecium and E. faecalis, despite their close phylogenetic relationship. The high content of plasmid and mobile genetic elements in E. faecium human lineages seems to be relevant to the emergence and persistence of their antibiotic resistance.

It is important to note that multiple drug resistance was not observed in food enterococci. Besides, it was not detected a clonal relationship between hospital-origin and food vancomycin-resistant $E$. faecium. Hammerum [17] considered that E. faecium isolates of animal origin are not themselves a hazard to humans, but they could act as donors of antimicrobial resistance genes to other pathogenic bacteria. The same variants of the van $A$ gene cluster, encoding for vancomycin resistance, have been observed in human and animal origin enterococci [49].

During 2013, in this study, in 10 patients with invasive infections, HLGR E. faecalis (40\%) were detected. In Argentina, in 2014, according to WHONET Argentina, clinical HLGR E. faecalis $(21.3 \%)$ 
Citation: Pourcel G, Sparo M, Corso A, Delpech G, Gagetti P, et al. (2017) Molecular Genetic Profiling of Clinical and Foodborne Strains of Enterococci with High Level Resistance to Gentamicin and Vancomycin. Clin Microbiol 6: 272. doi:10.4172/2327-5073.1000272

Page 7 of 8

were recovered (http://antimicrobianos.com.ar/2016/01/informeresistencia-2014-argentina/).

In this research, $3 / 14(21.4 \%)$ food $E$. faecalis showed high-level gentamicin resistance. In Germany, Peters et al. [50] reported a low prevalence of HLGR enterococci isolated from food of animal origin.

In the current study, all characterized HLGR E. faecalis were not multi-resistant and showed a high prevalence of cylA gene. Additionally, $\operatorname{aac}\left(6^{\prime}\right)$ - Ie- aph( $\left.2^{\prime \prime}\right)$-Ia gene was detected in all the isolates. Previously, in the same region, Sparo et al. [27] detected the spread of HLGR E. faecalis and this aminoglycoside resistance determinant in enterococci recovered from food, food producing animals and humans.

In human HLGR E. faecalis, different clonal types were observed (EFA-A, EFA-B, EFA-C). Previously, Murray et al. [51] found that several $E$. faecalis isolates with high-level gentamicin resistance from same and different locations presented distinct PFGE patterns. Few studies have shown the existence of clonal relationship between clinical isolates of $E$. faecalis. In this line, Larsen et al. [52] found HLGR $E$. faecalis ST16 with similar PFGE types, isolated from pigs, pork, nonhospitalized humans and patients with endocarditis. In the present research, the clonal type EFA-A isolates were distributed among food and human samples (minced meat, abdominal fluid and hemoculture). Food isolates were recovered from the same establishment (ET4) and processing period. These results showed the first evidence of clonal spread between human and food HLGR E. faecalis in Argentina. In Europe, Freitas et al. [53] observed the dissemination of a multidrugresistant E. faecalis clone in animals and humans. Presence of transferable resistance mechanisms in food isolates constitutes a risk for humans through the food chain. Sparo et al. [2] proved in vivo horizontal transfer of high-level gentamicin resistance between intestinal microbiota and food E. faecalis strains.

Therefore, presence of mobile genes such as $\operatorname{van} A$ in $E$. faecium, and $a a c(6)-I e-a p h\left(2^{\prime \prime}\right)-I a$ in $E$. faecalis implies the need of a continuous sureveillance of these strains in hospitals and community settings [54].

\section{Conclusion}

In summary, in Argentina, there has not been so far evidence regarding the clonal relationship between food and human enterococcal strains. This is the first study that showed clonal relationship between $E$. faecalis with high-level gentamicin resistance isolated from food and humans. van $A$ E. faecium strains from hospital origin belong to different clonal types than $E$. faecium from animal food; although, it is important to emphasize that the number of isolates tested is small. Food $\operatorname{van} A$ E. faecium were not identified as a direct cause of resistant enterococci in humans, but they could pose a risk for the intra or inter genus transfer of $\operatorname{van} A$ resistance determinant to human-adapted strains.

Finally, this study demonstrated the spread of strains of $\operatorname{van} A E$. faecium and HLGR $E$. faecalis of different origin in the ecosystem, with potential for horizontal transfer resistance to other bacteria.

\section{Author's Contributions}

GP, MMDL and JB provided the samples for the study. GP, SL and CS were in charge of phenotypic characterization of isolates. AC and PG carried out molecular characterization. GD, SL and CS studied antimicrobial resistance. GD, JAB and MS analyzed results coordinated the different stages of the study. GP and JAB were responsible for an internal review of the study. GP, GD and MS were in charge of the writing of the manuscript.

\section{Compliance with Ethical Standards}

\section{Ethical approval}

Samples from human participants were obtained under Medical prescription. International and local legislation was followed. This article does not contain any studies with animals performed by any of the authors.

\section{References}

1. Tenover FC, McDonald LC (2005) Vancomycin-resistant staphylococci and enterococci: epidemiology and control. Curr Opin Infect Dis 18: 300-305.

2. Sparo M, Urbizu L, Solana MV, Pourcel G, Delpech G, et al. (2012) High level resistance to gentamicin: genetic transfer between Enterococcus faecalis isolated from food of animal origin and human microbiota. Lett Appl Microbiol 54: 119-125.

3. Giraffa G (2003) Functionality of enterococci in dairy products. Int J Food Microbiol 88: 215-222.

4. Sparo M, Nuñez GG, Castro M, Calcagno ML, García Allende MA, et al. (2008) Characteristics of an environmental strain, Enterococcus faecalis CECT7121 and its effects as additive on craft dry-fermented sausages. Food Microbiol 25: 607-615.

5. Gentile JH, Sparo MD, Pipo VB, Gallo AJ (1995) Meningitis due to Enterococcus faecalis. Medicina (B. Aires) 55: 435-437.

6. Lark RL, Chenoweth C, Saint S, Zemencuk JK, Lipsky BA, et al. (2000) Four year prospective evaluation of nosocomial bacteremia: epidemiology, microbiology, and patient outcome. Diagn Microbiol Infect Dis 38: 131-140.

7. Safdar N, O'Horo JC, Maki DG (2013) Arterial catheter-related bloodstream infection: incidence, pathogenesis, risk factors and prevention. J Hosp Infect 85: 189-195.

8. Ceci M, Delpech G, Sparo M, Mezzina V, Sánchez Bruni S, et al. (2015) Clinical and microbiological features of bacteremia caused by Enterococcus faecalis. J Infect Dev Ctries 9: 1195-1203.

9. Bradley CR, Fraise AP (1996) Heat and chemical resistance of enterococci. J Hosp Infect 34: 191-196.

10. Cattoir V, Leclercq R (2010) Enterococci resistant to glycopeptides. Med Sci (Paris) 26: 936-942.

11. Xu X, Lin D, Yan G, Ye X, Wu S, et al. (2010) vanM, a new glycopeptide resistance gene cluster found in Enterococcus faecium. Antimicrob Agents Chemother 54: 4643-4647.

12. Cercenado E (2011) Enterococcus: phenotype and genotype resistance and epidemiology in Spain. Enferm Infecc Microbiol Clin 29: 59-65.

13. Leclercq R, Deriot E, Duval J, Courvalin P (1988) Plasmid-mediated resistance to vancomycin and teicoplanin in Enterococcus faecium. $\mathrm{N}$ Engl J Med 319: 157-161.

14. Bonten MJ, Willems R, Weinstein RA (2001) Vancomycin-resistant enterococci: why are they here, and where do they come from? Lancet Infect Dis 1: 314-325.

15. Werner G, Coque TM, Hammerum AM, Hope R, Hryniewicz W, et al. (2008) Emergence and spread of vancomycin resistance among enterococci in Europe. Euro Surveill 13: 19046

16. Coque TM, Tomayko JF, Ricke SC, Okhyusen PC, Murray BE (1996) Vancomycin-resistant enterococci from nosocomial, community and animal sources in the United States. Antimicrob Agents Chemother 40: 2605-2609.

17. Hammerum AM (2012) Enterococci of animal origin and their significance for public health. Clin Microbiol Infect 18: 619-625. 
18. Delpech G, Pourcel G, Schell C, De Luca M, Basualdo J, et al. (2012) Antimicrobial resistance profiles of Enterococcus faecalis and Enterococcus faecium isolated from artisanal food of animal origin in Argentina. Foodborne Pathog Dis 9: 939-944.

19. Ramsey AM, Zilberberg MD (2009) Secular trends of hospitalization with vancomycin-resistant Enterococcus infection in the United States, 2000-2006. Infect Control Hosp Epidemiol 30: 184-186.

20. Willems RJ, Bonten MJ (2007) Glycopeptide-resistant enterococci: deciphering virulence, resistance and epidemicity. Curr Opin Infect Dis 20: 384-390.

21. Ubeda C, Taur Y, Jenq RR, Equinda MJ, Son T, et al. (2010) Vancomycinresistant Enterococcus domination of intestinal microbiota is enabled by antibiotic treatment in mice and precedes bloodstream invasion in humans. J Clin Invest 120: 4332-4341.

22. Thaker MN, Kalan L, Waglechner N, Eshaghi A, Patel SN, et al. (2015) Vancomycin-variable enterococci can give rise to constitutive resistance during antibiotic therapy. Antimicrob Agents Chemother 59: 1405-1410.

23. Panesso D, Reyes J, Rincón S, Díaz L, Galloway-Peña J, et al. (2010) Molecular epidemiology of vancomycin-resistant Enterococcus faecium: a prospective, multicenter study in South American hospitals. J Clin Microbiol 48: 1562-1569.

24. Corso AC, Gagetti PS, Rodriguez MM, Melano RG, Ceriana PG, et al. (2007) Molecular epidemiology of vancomycin-resistant Enterococcus faecium in Argentina. Int J Infect Dis 11: 69-75.

25. Leavis H, Top J, Shankar N, Borgen K, Bonten M, et al. (2004) A novel putative enterococcal pathogenicity island linked to the esp virulence gene of Enterococcus faecium and associated with epidemicity. J Bacteriol 186: $672-682$.

26. Delpech G, Sparo M, Pourcel G, Schell C, De Luca MM, et al. (2013) Enterococcus spp. isolated from sheep cheese: resistance to antimicrobials used in clinics. Rev Soc Ven Microbiol 33: 129-133.

27. Sparo M, Delpech G, Pourcel G, Schell C, de Luca MM, et al. (2013) Cytolysin and high-level gentamicin resistance in Enterococcus faecalis from different origin. RAZ y EIE 8: 5-10.

28. Sparo M, Delpech G (2014) High-level gentamicin resistance in Enterococcus faecalis: molecular characteristics and relevance in severe infections. In Enterococcus faecalis: Molecular Characteristics, Role in Nosocomial Infections and Antibacterial Effects, pp. 93-108. Nova Science Publishers, Inc. Hauppauge, NY.

29. Ramirez MS, Tolmasky ME (2010) Aminoglycoside modifying enzymes. Drug Resist Updat 13: 151-171.

30. Coburn PS, Gilmore MS (2003) The Enterococcus faecalis cytolysin: a novel toxin active against eukaryotic and prokaryotic cells. Cell Microbiol 5: 661-669.

31. Giridhara Upadhyaya PMG, Ravikumar KL, Umapathy BL (2009) Review of virulence factors of Enterococcus: an emerging nosocomial pathogen. Indian J Med Microbiol 27: 301-305

32. Huycke MM, Spiegel CA, Gilmore MS (1991) Bacteremia caused by hemolytic high-level gentamicin-resistant . Antimicrob Agents Chemother 35: 1626-1634.

33. Dupont H, Vael C, Muller-Serieys C, Chosidow D, Mantz J, et al. (2008) Prospective evaluation of virulence factors of enterococci isolated from patients with peritonitis: impact on outcome. Diagn Microbiol Infect Dis 60: 247-253.

34. Clinical and Laboratory Standards Institute (2015) Performance standards for antimicrobial susceptibility testing, 25th Informational Supplement. CLSI document M100-S25. CLSI: Wayne, PA.

35. Bittencourt de Marques E, Suzart S (2004) Occurrence of virulenceassociated genes in clinical Enterococcus faecalis strains isolated in Londrina, Brazil. J Med Microbiol 53: 1069-1073.

36. Ke D, Picard FJ, Martineau F, Ménard PHR, Ouellette M, et al. (1999) Development of a PCR assay for rapid detection of enterococci. J Clin Microbiol 37: 3497-3503.
37. Dutka-Malen S, Evers S, Courvalin P (1995) Detection of glycopeptide resistance genotypes and identification to the species level of clinically relevant enterococci by PCR. J Clin Microbiol 33: 24-27.

38. Coque TM, Willems R, Cantón R, Del Campo R, Baquero F (2002) High occurrence of esp among ampicillin-resistant and vancomycinsusceptible Enterococcus faecium clones from hospitalized patients. J Antimicrob Chemother 50: 1035-1038.

39. Tenover FC, Arbeit RD, Goering RV, Mickelsen PA, Murray BE, et al. (1995) Interpreting chromosomal DNA restriction patterns produced by pulsed-field gel electrophoresis: criteria for bacterial strain typing. J Clin Microbiol 33: 2233-2239.

40. Barbosa J, Ferreira V, Teixeira P (2009) Antibiotic susceptibility of enterococci isolated from traditional fermented meat products. Food Microbiol 26: 527-532.

41. Ribeiro T, Oliveira M, Fraqueza MJ, Lauková A, Elias M, et al. (2011) Antibiotic resistance and virulence factors among Enterococci isolated from chouriço, a traditional Portuguese dry fermented sausage. J Food Prot 74: 465-469.

42. Centers for Disease Control and Prevention (2002) Staphylococcus aureus resistant to vancomycin-United States. MMWR Morb Mortal Wkly Rep 51: 565-567.

43. Sievert DM, Ricks P, Edwards JR, Schneider A, Patel J, et al. (2013) Antimicrobial-resistant pathogens associated with healthcare-associated infections: summary of data reported to the National Healthcare Safety Network at the Centers for Disease Control and Prevention, 2009-2010. Infect Control Hosp Epidemiol 34: 1-14.

44. The European Antimicrobial Resistance Surveillance System (2015) EARS-Net Results.

45. Kalocheretis P, Baimakou E, Zerbala S, Papaparaskevas J, Makriniotou I, et al. (2004) Dissemination of vancomycin-resistant enterococci among haemodialysis patients in Athens, Greece. J Antimicrob Chemother 54: 1031-1034.

46. Willems RJ, van Schaik W (2009) Transition of Enterococcus faecium from commensal organism to nosocomial pathogen. Future Microbiol 4: 1125-1135.

47. Willems RJ, Top J, van Santen M, Robinson DA, Coque TM, et al. (2005) Global spread of vancomycin-resistant Enterococcus faecium from distinct nosocomial genetic complex. Emerg Infect Dis 11: 821-828.

48. Leavis HL, Bonten MJ, Willems RJ (2006) Identification of high-risk enterococcal clonal complexes: global dispersion and antibiotic resistance. Curr Opin Microbiol 9: 454-460.

49. Novais C, Freitas AR, Sousa JC, Baquero F, Coque TM, et al. (2008) Diversity of Tn1546 and its role in the dissemination of vancomycinresistant enterococci in Portugal. Antimicrob Agents Chemother 52: 1001-1008.

50. Peters J, Mac K, Wichmann-Schauer H, Klein G, Ellerbroek L (2003) Species distribution and antibiotic resistance patterns of enterococci isolated from food of animal origin in Germany. Int J Food Microbiol 88: 311-314.

51. Murray BE, Singh KV, Heath JD, Sharma BR, Weinstock GM (1990) Comparison of genomic DNAs of different enterococcal isolates using restriction endonucleases with infrequent recognition sites. J Clin Microbiol 28: 2059-2063

52. Larsen J, Schønheyder HC, Lester CH, Olsen SS, Porsbo LJ, et al. (2010) Porcine-origin gentamicin resistant Enterococcus faecalis in humans, Denmark. Emerg Infect Dis 16: 682-684.

53. Freitas AR, Coque TM, Novais C, Hammerum AM, Lester $\mathrm{CH}$, et al. (2011) Human and swine hosts share vancomycin-resistant Enterococcus faecium CC17 and CC5 and Enterococcus faecalis CC2 clonal clusters harboring Tn1546 on indistinguishable plasmids. J Clin Microbiol 49: 925-931.

54. Muto CA, Jernigan JA, Ostrowsky BE, Richet HM, Jarvis WR, et al. (2003) SHEA guideline for preventing nosocomial transmission of multidrug-resistant strains of Staphylococcus aureus and Enterococcus. Infect Control Hosp Epidemiol 24: 362-386. 